\title{
Detection of Blood Protozoa Infecting Broiler Chicken Farms in Tanjung Gunung Village, District Jombang
}

\section{Deteksi Protozoa Darah yang Menginfeksi Ayam Ras Pedaging di Peternakan desa Tanjung Gunung, Kabupaten Jombang}

\author{
${ }^{1)}$ Marchelia Arifiandani, ${ }^{2)}$ Endang Suprihati, ${ }^{3)}$ Wiwik Misaco Yuniarti, ${ }^{2}$ Nunuk Dyah Retno \\ Lastuti, ${ }^{2)}$ Poedji Hastutiek, ${ }^{4}$ Sunaryo Hadi Warsito \\ ${ }^{1)}$ Student, Faculty of Veterinary Medicine, Universitas Airlangga. \\ ${ }^{2)}$ Department of Veterinary Parasitology, Faculty of Veterinary Medicine, Universitas Airlangga. \\ 3) Department of Veterinary Clinic, Faculty of Veterinary Medicine, Universitas Airlangga. \\ 4)Department of Veterinary Poultry, Faculty of Veterinary Medicine, Universitas Airlangga. \\ Received: 25-02-2019, Accepted: 10-03-2019, Published Online: 19-03-2019
}

\begin{abstract}
Broiler chicken farms could be a part of potential source infection Leucocytozoonosis and Plasmodiosis disease due to the death of livestock. Broiler farms in Tanjung Gunung, District Jombang near the fields, water, and trees. This could be increase the population of vectors infection Leucocytozoonosis and Plasmodiosis. The main purpose of this researchis to detect Leucocytozoonosis and Plasmodiosis infections on broiler farms in Tnjung Gunung Village, District Jombang using 50 broiler chickens by Purposive Sampling of 2 bredeers. The result show rhat there are 6 positive samples infected Leucocytozoonosis, while Plasmodiosis infection could not be fond. Need cage sanitation to break life cycles of vector Leucocytozoonosis and Plasmodiosis.
\end{abstract}

\section{Keywords : Leucocytozoonosis, Plasmodiosis, a risk of vector, broiler}

\section{Pendahuluan}

Peternakan unggas khususnya ayam merupakan komoditi ternak yang cukup tinggi populasinya dan sangat berpotensi untuk meningkatkan perekonomian masyarakat di Indonesia. Kebutuhan akan daging ayam sangat tinggi karena konsumsi masyarakat yang mayoritas mengkonsumsi daging (Supartono dan Yunus, 200o). Ternak ayam yang biasa diternakkan oleh peternak adalah ayam pedaging atau yang sering disebut dengan ayam broiler (Ditjennak, 2014). Pada umumnya peternakan ayam di Indonesia menggunakan sistem kandang terbuka yang merupakan salah satu penyebab terjadinya Leucocytozoonosis yang disebabkan $L$. caulleryi yang merupakan spesies patogen pada ayam (You et al., 2000).

Jombang memiliki potensi yang cukup bagus di sektor peternakan antara lain dalam usaha budi daya ternak, baik ternak potong maupun pembibitan serta usaha produksi dan pengelolahan hasil ternak. Menurut Dinas Peternakan Jombang (2015) salah satu ternak yang sering diternakan oleh masyarakat Jombang dan memiliki produksi terbanyak yaitu ayam ras pedaging dengan tingkat produksi sebanyak 1312 ton per tahun.
Peternakan ayam ras pedaging di Desa Tanjung Gunung, Kabupaten Jombang merupakan salah satu peternakan dengan sistem intensif terbuka, tipe kandang panggung yang berlokasi di area persawahan, berlumpur, terdapat aliran parit berair, pepohonan dan semak-semak yang berada dibelakang peternakan. Menurut Hastutiek dkk. (200o) daerah dekat sungai, selokan, parit berair yang tidak deras aliranya, dekat rawa, kolam, sawah, tempat berair lainnya yang airnya tidak mengalir atau mengalir dengan tenang merupakan lingkungan yang memenuhi persyaratan bagi kelangsungan hidup Culicoides sp., semua tempat ini berdekatan dengan pohon atau semak-semak yang rimbun sehingga lingkungannya juga gelap. Menurut Floore (2002) larva Culex sp. dapat ditemukan disegala jenis perairan termasuk perairan sawah dan kolam dangkal. Hal ini merupakan salah satu pendukung terjadinya Leucocytozoonosis dan Plasmodiosis akibat dari habitat vektor yang berada di lingkungan sekitar peternakan. Wahyuti (2003) melaporkan bahwa peternakan sekitar daerah Jombang positif terinfeksi Leucocytozoonosis setidaknya terdapat enam spesies Culicoides sp. 
Infeksi Leucocytozoonosis dan Plasmodiosis belum pernah dilaporkan terjadi di peternakan ayam ras pedaging di Desa Tanjung Gunung, Kabupaten Jombang, namun peternak mengatakan sering terjadi kematian ayam ras pedaging secara mendadak yang tidak pernah diketahui penyebabnya. Menurut pengamatan di lokasi peternakan dan informasi yang diberikan peternak maupun anak kandang ternak sebelum mati menunjukan gejala seperti Leucocytozoonosis dan Plasmodiosis yaitu lesu, lemah dan kurus karena nafsu makan turun (Purwanto dkk., 2009). Terdapat 2 peternakan yang berada di Desa Tanjung Gunung, Kabupaten Jombang dengan populasi pada peternakan I sebanyak 14.000 ekor dan 10.ooo ekor pada peternakan II.

Angka kematian unggas akibat penyakit Plasmodiosis di Indonesia mencapai 22\% dan pada kejadian akut angka mortalitasnya mencapai $80 \%$ (Poultry, 2006). Kerugian yang ditimbulkan oleh serangan Leucocytozoon sp. pada anak ayam baik ayam pedaging maupun petelur dapat menimbulkan gejala klinis $0-40 \%$ dan tingkat kematiannya mencapai $7-50 \%$, pada ayam dewasa dapat menimbulkan gejala klinis 7-40\% dan kematian 2-6o \% (Purwanto dkk., 2009).

Melihat dampak buruk infeksi Leucocytozoonosis dan Plasmodiosis yang mengancam peternakan ayam ras pedaging, maka perlu dilakukan penelitian untuk mengetahui keberadaan kedua parasit darah pada peternakan ayam ras pedaging di Desa Tanjung Gunung, Kabupaten Jombang.

\section{Metode Penelitian}

Penelitian ini merupakan penelitian deskriptif untuk mendeteksi kejadian Leucocytozoonosis dan Plasmodiosis pada ayam ras pedaging di peternakan Desa Tanjung Gunung, Kabupaten Jombang. Teknik pengambilan sampel menggunakan purposive sampling dengan kriteria pengambilan sampel berdasarkan gejala klinis yang mengarah pada infeksi Leucocytozoonosis dan Plasmodiosis yang dapat diamati di lapangan. Pemeriksaan menggunakan metode ulas darah menggunakan 50 ayam ras pedaging yang di ambil dari dua peternakan.
Bahan yang digunakan adalah methanol 96\% untuk fiksasi preparat ulas darah, zat pewarna Giemsa $10 \%$ untuk mewarnai preparat ulas darah, alkohol $70 \%$ digunakan saat mengambil darah ayam dan minyak emersi untuk memperjelas obyek pada saat diamati di mikroskop. Darah diambil melalui vena brachialis bagian sayap menggunakan spuit berukuran 3 $\mathrm{ml}$, kemudian sampel darah langsung ditampung di tabung yang mengandung Ethylene diamine tetraacetic acid EDTA tutup botol berwarna ungu yang sudah berisi antikoagulan agar darah tidak menggumpal saat disimpan, lalu diberi label berisi keterangan nomor ayam, tanggal, dan waktu pengambilan. Tabung EDTA yang berisi sampel darah kemudian dimasukkan didalam kotak pendingin. Pembuatan preparat ulas dilakukan dengan cara sampel darah yang sudah ditampung di tabung yang mengandung EDTA diteteskan pada salah satu ujung dari gelas objek yang bersih kemudian dengan gelas objek yang lain diletakkan dekat dengan tetesan darah membentuk sudut $30^{\circ}$. Gelas objek digeser kearah tetesan darah sehingga darah tersebar ke seluruh permukaan gelas objek, dengan cepat, gelas objek digeser berlawanan dengan arah tadi sehingga darah akan merata diatas gelas obyek sebagai lapisan yang tipis (Bijanti dkk., 2010).

Gelas objek dikeringkan dengan menggoyang-goyangkan di udara atau dianginanginkan, jika sudah kering difiksasi dengan Methanol 96\% selama 2-3 menit, setelah itu preparat diwarnai dengan larutan Giemsa $10 \%$ dalam larutan buffer selama 30 menit, kemudian dicuci dengan air lalu dikeringkan dan diberi label pengambilan, lalu diperiksa menggunakan mikroskop perbesaran 100ox menggunakan minyak emersi.

\section{Hasil dan Pembahasan}

Pemeriksaan menggunakan metode ulas darah menunjukkan sampel positif Leucocytozoon caulleryi.. Berdasarkan jumlah sampel yang diperiksa dikelompokkan berdasarkan lokasi peternakan dapat dilihat pada Tabel 1.

Tabel 1. Hasil pemeriksaan sampel darah ayam terhadap Leuococytozoon sp.

\begin{tabular}{ccccc}
\hline Peternakan & Jumlah Sampel & Sampel Positif & Sampel Negatif & Presentase \\
\hline I & 35 & 5 & 30 & $14,2 \%$ \\
II & 15 & 1 & 14 & $6,6 \%$ \\
Jumlah & 50 & 6 & 44 & \\
\hline
\end{tabular}


Hasil penelitian menunjukkan bahwa pemeriksaan melalui ulas darah yang menggunakan 50 sampel darah ayam ras pedaging di peternakan I terdapat 5 sampel postif Leucocytozoon sp. dan 30 sampel negatif Leucocytozoon sp. dengan presentase $14,2 \%$. Hasil pemeriksaan ulas darah pada ayam ras pedaging di peternakan I dapat dilihat pada Gambar 1.

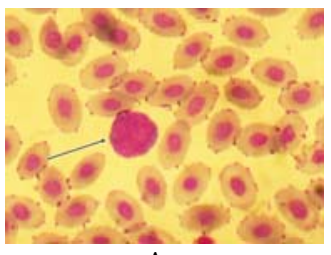

A

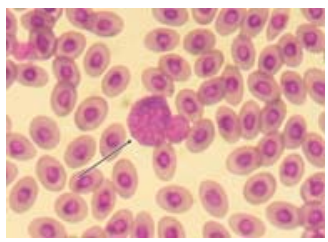

C

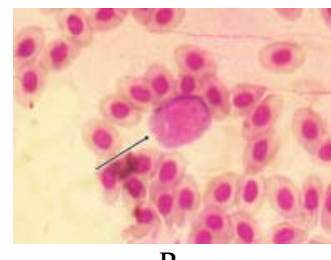

B

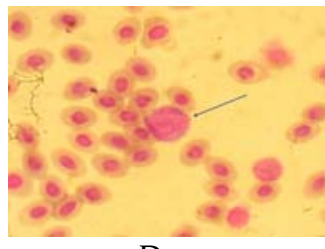

D
Gambar 1. Gambaran mikroskopis gametosit Leucocytozoon caulleryi ayam ras pedaging di peternakan I gambar (A,B,C,D,) di Desa Tanjung Gunung, Kabupaten Jombang dengan pewarnaan Giemsa danperbesaran $1000 \mathrm{x}$.

Pada peternakan II terdapat 1 sampel positif Leucocytozoon sp. dan 14 sampel negatif Leucocytozoon sp. yang ditemukan dengan presentase 6,6\%. Hasil pemeriksaan ulas darah pada ayam ras pedaging di peternakan II dapat dilihat pada Gambar 2.

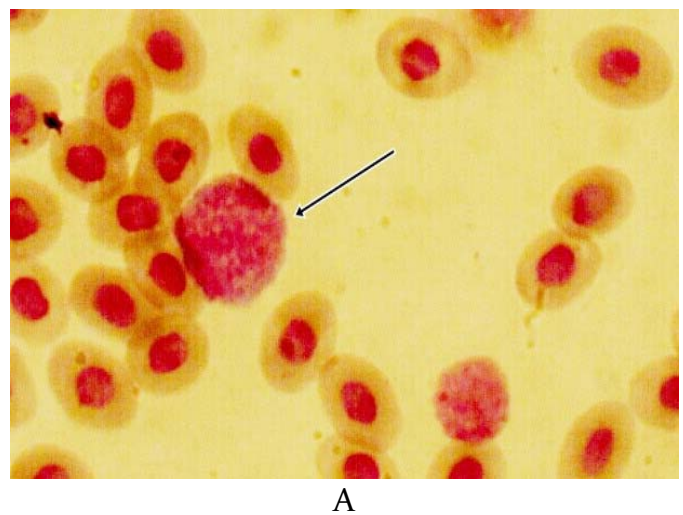

Gambar 2. Gambaran mikroskopis gametosit Leucocytozoon caulleryi ayam ras pedaging di peternakan II gambar A di Desa Tanjung Gunung, Kabupaten Jombang dengan pewarnaan Giemsa dan perbesaran $1000 \mathrm{x}$.
Hasil positif ini dibuktikan dengan ditemukan fase gametosit Leucocytozoon caulleryi pada hasil pemeriksaan ulas darah dengan ciri-ciri berbentuk bulat membentuk fusi dengan sel induk semang dan tidak ada pemanjangan dari sitoplasma sel induk semang. Eritrosit mengalami distorsi akibat dari ukuran parasit yang lebih besar dan inti eritrosit berada di tepi parasit (Suprihati, 2013).

Pada penelitian ini infeksi Plasmodiosis yang disebabkan oleh Plasmodium sp. tidak ditemukan, dengan tidak ditemukanya bentukan gametosit dari Plasmodim sp. Hasil negatif infeksi Plasmodiosis dapat dilihat pada Tabel 2.

Tabel 2. Hasil pemeriksaan sampel darah ayam terhadap Plasmodium sp.

\begin{tabular}{ccccc}
\hline Peternakan & $\begin{array}{c}\text { Jumlah } \\
\text { sampel }\end{array}$ & $\begin{array}{c}\text { Sampel } \\
\text { Positif }\end{array}$ & $\begin{array}{c}\text { Sampel } \\
\text { Negatif }\end{array}$ & Presentase \\
\hline I & 35 & o & 35 & 0\% \\
II & 15 & o & 15 & o\% \\
Jumlah & 50 & o & 50 & \\
\hline
\end{tabular}

Pemeriksaan ulas darah yang menggunakan 50 sampel darah ayam ras pedaging di peternakan I sebanyak 35 sampel terdapat o sampel positif Plasmodium sp. dan 35 sampel negatif Plasmodium sp. dan pada peternakan II terdapat o sampel positif Plasmodium sp. dan 15 sampel negatif Plasmodium sp. darah. Hasil penelitian menunjukkan bahwa tidak ditemukan bentukan Plasmodium sp. pada 50 sampel darah ayam ras pedaging.

Vektor penyebar penyebab terjadinya Leucocytozoonosis yang disebabkan oleh Leucocytozoon caulleryi yaitu Culicoides sp. yang di Indonesia ditularkan oleh Culicoides arakawae ditemukan di area perkandangan. Culicoides sp. adalah lalat penghisap yang memiliki ukuran tubuh amat kecil yaitu 1-3 mm, memiliki antena yang panjangnya lebih dari 6 segmen dan sayapnya berbintik-bintik (Wahyuti, 2003).

Vektor penyebaran Leucocytozoonosis yaitu Culicoides sp. dapat ditemukan area perkandangan tepat di bawah kandang yang terdapat banyak kotoran ternak. Berdasarkan pengamatan terhadap faktor penyebab yang berpengaruh terhadap terjadinya Leucocytozoonosis bahwa sistem perkandangan dan sanitasi serta lokasi peternakan merupakan faktor utama terhadap penyebaran penyakit. Oleh karena itu upaya yang dapat dilakukan untuk menekan terjadinya infeksi Leucocytozoonosis dengan memperhatikan sanitasi kandang dan lingkungan sekitarnya untuk mengurangi dan 
menekan populasi vektor penyebaran dengan meniadakan tempat perkembangbiakan vektor (Akoso, 2002).

\section{Kesimpulan}

Infeksi Leucocytozoonosis terdeteksi pada peternakan ayam ras pedaging di Desa Tanjung Gunung, Kabupaten Jombang dengan morfologi yang khas seperti Leucocytozoon caulleryi dengan presentase $14,2 \%$ pada peternakan I dan 6,6 \% pada peternakan II, sedangkan infeksi Plasmodiosis tidak ditemukan.

\section{Daftar Pustaka}

Akoso, T. B. 2002. Kesehatan Unggas. Kanisius. Yogyakarta. hal: 105-106.

Bijanti, R., Utomo, R.B., Wahyuni, R.S., Budhy, S., dan Yuliani, M. G. A. 2010. Penuntun Praktikum Patologi Klinik Veteriner. Fakultas Kedokteran Hewan. Universitas Airlangga. Surabaya. hal: 27.

Dinas Peternakan dan Perikanan Jombang. 2015. [diunduh april 2017]. Tersedia pada: http://www.jombangkab.go.id.

[Ditjennak] Direktorat Jenderal Peternakan dan Kesehatan Hewan. 2014. Manual Penyakit Unggas Cetakan Kedua. [diunduh April 2017]. Tersedia pada: http://www.ditjennak. pertanian.go.id.

Floore, T. 2002. Mosquito Information The American Mosquito Control Association, pheree famu. [diunduh April 2017]. Tersedia pada: http://www.org/mosquito. html.

Poultry. 2006. Apa Itu Malaria.[ diunduh April 2017]. Tersedia pada: http://www.poultryindonesia.com/modules.php?name $=$ New\& file $=$ article $\&$ sid $=997$.

Votypka, J. 2004. Blood Parasites of Birds and Their Vectors. Summary of Ph.D. [Thesis].

Wahyuti, R. N. 2003. Potensi Lalat terhadap Prevalensi Leucocytozoonosis pada Ayam. [Tesis]. Program Pasca Sarjana. Universitas Airlangga. Surabaya.

You, Y.C, Jiunn-Siow Wang and Ching-Chang Yeh, 200o. Culicoides arakawae (Dipetera: Ceratopogonidae) Population Succession in Relation to Leucocytozoonosis Prevalence on a Chicken Farm in Taiwan. Vet. Parasitol. 93: 113-12. 